\title{
FERRITIN IN SYNOVIAL CELLS IN PATIENTS WITH RHEUMATOID ARTHRITIS
}

\author{
BY \\ K. D. MUIRDEN \\ From the University of Melbourne Department of Medicine, \\ The Royal Melbourne Hospital Post Office, Victoria, Australia
}

\begin{abstract}
Although the lesions of rheumatoid arthritis occur throughout the body tissues, it is the synovial membrane which shows the most constant and usually the earliest changes. The characteristic features revealed by the light microscope are proliferation of synovial lining cells, infiltration with inflammatory cells including collections of plasma cells and lymphocytes, and increased vascularity. Areas of fibrinoid degeneration may occur and the synovial surface may be covered with plaques of fibrin itself. Unlike the pathological features of the rheumatoid nodule, however, none of these changes can be considered specific for this disease. For this reason the ultrastructural details of the rheumatoid synovial membrane have particular interest.
\end{abstract}

In recent years the fine structure of the normal synovium in man and animals has been described. Barland, Novikoff, and Hamerman (1962) first noted that the synovial lining cells could be classified into two morphological types (which may represent two states of functional activity of a single cell type) designated as types A and B. The type A cell was characterized by numerous filopodia, large vacuoles, many vesicles, a prominent Golgi zone, scanty endoplasmic reticulum, and numerous mitochondria. The less common type B cell contained abundant endoplasmic reticulum but few vacuoles and vesicles. It must be added that from personal experience with human, rabbit, and guinea-pig material, it is clear that cells which are less well defined or are intermediate in form are commonly found. Unfortunately, the Japanese workers Hirohata, Mizuhara, Fujiwara, Sato, Imura, and Kobayashi (1963) have called the cell types $M$ and $F$ respectively, with $F M$ as an intermediate type. The designation " $M$ " stands for macrophage and support for this view of the cells' function has been provided by the experiments of Chapman, Muirden, Ball, and Hyde (1962), Muirden (1963), and Cochrane, Davies, and Palfrey (1965). In these studies electron dense material injected into joints was found to localize predominantly in the

*This study was made possible by grants from the National Health and Medical Research Council of Australia and the Victor Hurley Fund of the Royal Melbourne Hospital. type A or $\mathrm{M}$ cell. The function of the type $\mathrm{B}$ or $\mathrm{F}$ (for fibroblast-like) cells is more conjectural, but discussion centres in their role in the synthesis and secretion of protein and mucopolysaccharide (Wyllie, More, and Haust, 1964).

Less is known about the fine structure and function of the diseased synovium and few electron micrographs have been published. Barland, Novikoff, and Hamerman (1964) have described changes in the type A cell, of which the most striking was the presence of large cytoplasmic granules considered to be lysosomes. Norton and Ziff (1964) have shown that the proliferating rheumatoid synovial cells retain their phagocytic properties. Hirohata and Kobayashi (1964) in a more extensive study have also emphasized the lysosomal content of the A or M type cell. They also note but do not illustrate the fact that ferritin granules occur sporadically in the cytoplasm of some of the cells.

The purpose of this paper is to report the ultrastructural details of three consecutive biopsy specimens obtained at open operation in patients with classical rheumatoid arthritis. In all three specimens the most striking feature was the presence of large numbers of ferritin molecules in the synovial lining cells. These were frequently concentrated into complex cytoplasmic granules or lysosomes. The possible significance of this finding in relation to the anaemia and pathogenesis of rheumatoid arthritis will be discussed.

\section{Material and Methods}

Previous experiments involving the examination of synovial membrane removed at surgical synovectomy had shown poor preservation of cellular detail. It was considered that this could be due to the use of a tourniquet which was frequently in place for more than $\mathbf{2 0}$ minutes before the tissue was removed and fixed. In the three cases to be described the period of anoxia produced by the tourniquet was kept to within 2 minutes in Cases 1 and 3, and in Case 2 a tourniquet was not used at all. After removal the tissue was immediately fixed in an ice-cold solution of 1 per cent. osmium tetroxide in veronal acetate buffer, $p \mathrm{H} 7.2$ to $7 \cdot 4$, to which was added $0.045 \mathrm{~g}$. sucrose per ml. fixative. The tissue was sliced into small pieces and transferred to further fixative. After fixation 
for 1 hour, the tissue was dehydrated with increasing concentrations of ethyl alcohol. The specimens were stained for 1 hour in 1 per cent. phosphotungstic acid in ethanol in the dehydration stage. Embedding was carried out in Araldite according to Glauert and Glauert (1958). The tissue was orientated with preliminary sections cut across the whole block face, restained with toluidin blue, and examined with a light microscope. Subsequently, thin sections were cut with a Huxley ultramicrotone using a glass knife, and these were mounted on carbon-coated grids. Sections were examined in a Hitachi IIA Electron microscope, the property of the Wellcome Trust. Adjacent areas of tissue removed at the time of surgery were fixed in formalin, embedded in paraffin, and stained with haematoxylin and eosin for general examination. Later sections from Cases 1 and 2 were stained for iron with the Prussian blue technique. Unfortunately no suitable tissue was available for this process from Case 3 .

\section{Clinical Details}

Case 1, a woman aged 70 years, was admitted to the Royal Melbourne Hospital in February, 1965. She gave a 20year history of generalized joint pains and for 1 year had suffered increased pain and swelling of the left knee. She had been treated with aspirin and "vaccines" in the past and for 6 months with low dosage prednisolone.

Examination.-There were typical rheumatoid changes in the hands and wrists and a grossly swollen unstable left knee. Other joints showed changes which were less marked but the other systems were normal.

Investigations.-Haemoglobin $7 \cdot 9$ g./100 ml., hypochromic normocytic anaemia; white blood cells $6,000 /$ mm. ${ }^{3}$ with a normal differential count; erythrocyte sedimentation rate $83 \mathrm{~mm}$. in $1 \mathrm{hr}$ (Westergren); sheep cell agglutination test $1: 2,040$; no L.E.-cells found; blood urea $69 \mathrm{mg} . / 100 \mathrm{ml}$.; serum iron $28 \mu \mathrm{g}$. per cent.

Stool occult bloods were positive and remained positive despite withdrawal of aspirin. A barium meal showed a hiatus hernia.

Progress. - 9 days before surgery the swollen left knee was aspirated and lightly blood-stained fluid removed. No injections were given into the joint at that stage nor had any been given previously. One day pre-operatively the patient was transfused with 3 pints of blood.

Surgery.-Synovectomy of the left knee was performed on March 4, 1965. The synovial fluid was not bloodstained when first released.

Case 2, a woman aged 50 years, was admitted to hospital in May, 1965.

History.-She gave a 17-year history of progressive and generalized joint disease with pain, stiffness, swelling, and deformity. The referring letter indicated that in 1961 she had been found to be anaemic with a haemoglobin of $8.5 \mathrm{~g} . / 100 \mathrm{ml}$., which failed to respond to oral or intramuscular iron; she had then been transfused with 4 pints of blood, and the haemoglobin rose to $13.8 \mathrm{~g} . / 100 \mathrm{ml}$. Later in the same / ear it had dropped to $10 \cdot 3$ g. $/ 100 \mathrm{ml}$. but investigation, including a barium meal, did not revea苂 any site of gastrointestinal blood loss and occult bloods were generally negative. Her treatment had consisted of aspirin and phenylbutazone.

The patient's admission was precipitated by increasing pain in the right hip and knee with stiffness and flexiore deformity.

Examination.-There were changes in the joints typicaథ̄ of rheumatoid arthritis but no other abnormalities.

Investigations.-Haemoglobin 10.9 g./100 ml., normo $\mathbb{\varnothing}$ chromic with normocytic anaemia; white blood cellos $9,000 / \mathrm{mm} .{ }^{3}$ with a normal differential count; erythrocyte sedimentation rate $51 \mathrm{~mm}$. in $1 \mathrm{hr}$ (Westergren); latex fixation test ++ ; no L.E.-cells found; serum iron $30 \mu$.. per cent.

$X$ rays of the right hip showed the combined changes of rheumatoid and osteo-arthritis.

Progress.-The patient was placed on full doses of aspirin and given oral iron therapy. Later, daily ACTH injections were given. The right hip received an intraw articular injection of prednisolone together with loca anaesthetic 5 weeks before surgery. After 4 weeks treatment, the haemoglobin had risen to 11.9 g. $/ 100 \mathrm{~mL}$

Surgery.-On July 15, 1965, a cup arthroplasty wa\& performed on the right hip and synovial tissue was re moved for examination. A blood transfusion was give during the course of operation.

Case 3, a man aged 50 years, was first seen in October, 1965 . He gave a 10-year history of progressive generalized jôn pain, swelling, and deformity, with prominent morng stiffness. He had been treated with aspirin and phexiy butazone and had received one gold injection 8 yeare previously. He had never received iron either by mout or injection and the only blood transfusion was give $\bar{P}$ during subsequent surgery. Intra-articular injection? had not been administered.

Examination.-There were typical rheumatoid change in the joints and large elbow nodules. The lateral metas tarso-phalangeal joints were subluxed and synovią thickening was present. Both liver and spleen were. moderately enlarged but there was no lymphadenopathy

Investigations.-Haemoglobin 12.4 g./100 ml., wit $\overline{\bar{P}}$ hypochromia and slight microcytosis; reticulocytes 3 per cent.; white blood cells $1,400 / \mathrm{mm}^{3}$, marked neutropenia with a shift to the left; erythrocyte sedimentation rate 56 $\mathrm{mm}$. in $1 \mathrm{hr}$ (Westergren); sheep cell agglutination tes 1 : 2,048; no L.E.-cells found; antinuclear factor positiveo gamma globulin $2 \cdot 9 \mathrm{~g}$. per cent.; serum iron $12 \mu \mathrm{g}$. per cent.

Stool occult blood negative.

Bone marrow-main abnormality a maturation arres in the myeloid series; stainable iron markedly reduced.

Progress.-It was concluded that in addition to rheumæ toid arthritis the patient also had Felty's syndrome. OfO November 18, 1965, he underwent surgery in which the lateral metatarsal heads and adjacent synovial tissue were excised. Postoperatively the neutropenia responded $t \frac{\delta}{\delta}$ corticosteroid therapy and the haemoglobin also rose 


\section{Observations}

Preliminary light microscopy of standard histological preparations demonstrated the typical features of rheumatoid synovitis as described in the introduction. In Cases 1 and 3 extensive proliferation of synovial cells was a feature, while in Case 2 the membrane was less cellular and more fibrous.

Electron microscopy revealed the synovial tissue to consist of cells roughly parallel and many layers thick (Fig. 1). The cells were usually close together

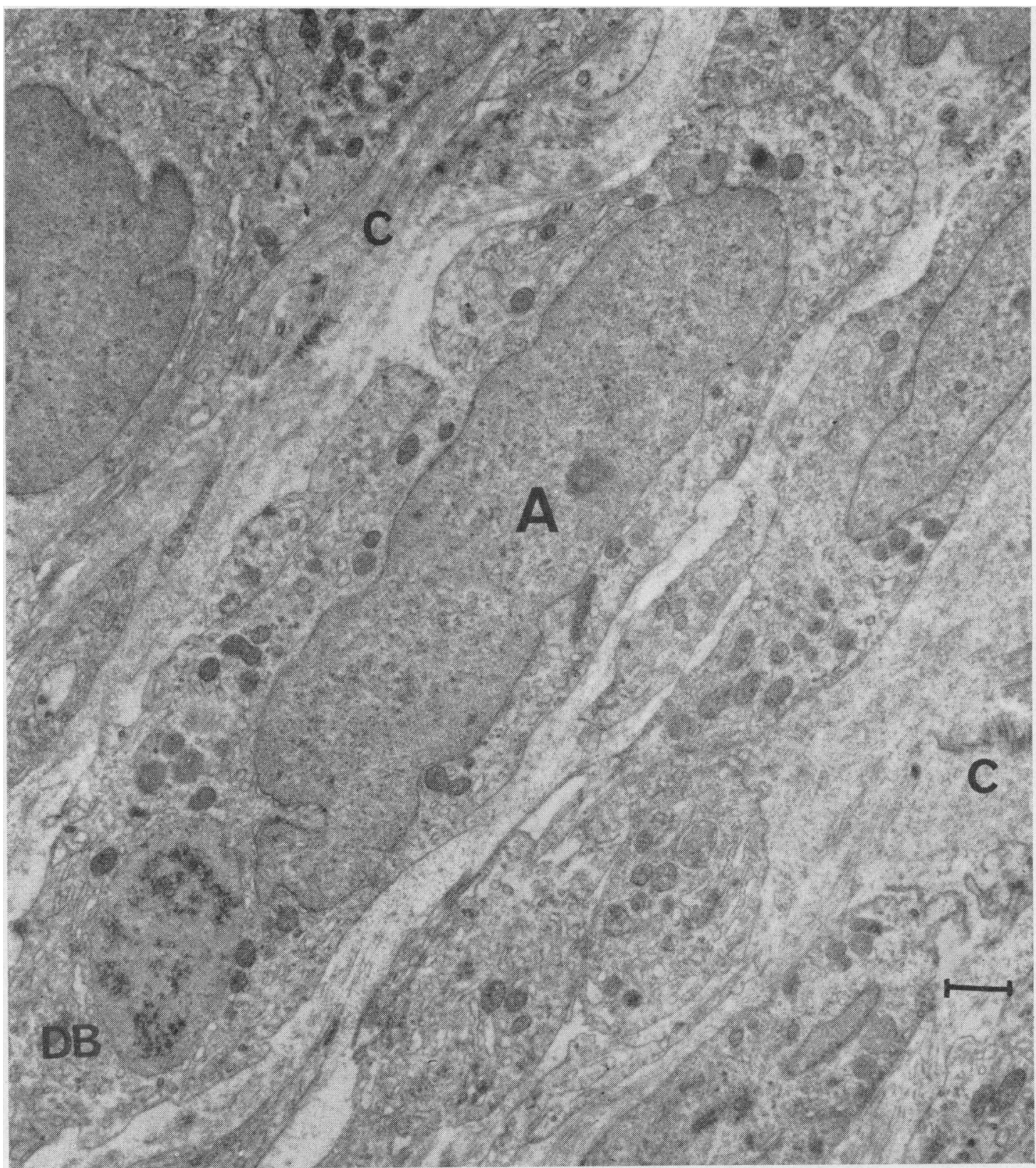

Fig. 1.-Case 1. Low-power electron micrograph showing synovial lining cells in sheets with small amounts of collagen (C) in the intercellular spaces. The central cell (A) contains a dense body (DB), diameter $3 \mu$., and many mitochondria. $\times 9,500$ approx. Scale marker 1 micron. 
but there were no attachment bodies between adjacent cells. Collagen fibres with normal appearances occurred in the spaces between cells particularly in the deeper layers. In the more superficial layers, the

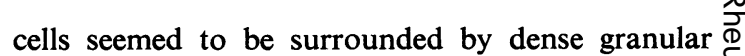
material which in places had a definite fibillary $\overline{3}$ structure. The fibrils, however, showed no banding $\square$ (Fig. 2). This appearance is virtually identical with

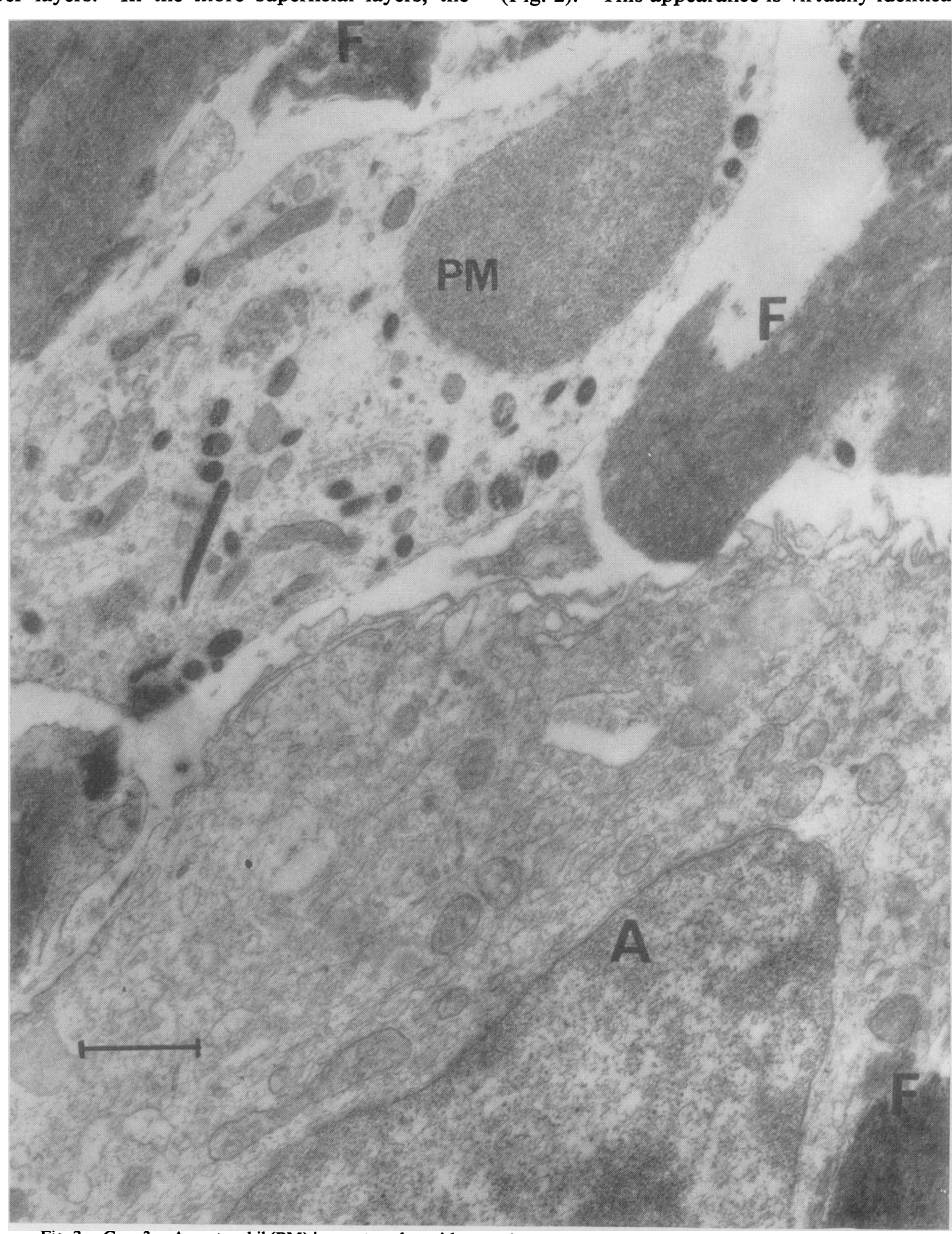

Fig. 2.-Case 3. A neutrophil (PM) is seen together with part of a type A synovial cell (A). The latter features prominent filopodia and cytoplasmic filaments. The extra-cellular spaces contain dense material (F) consisting of fine non-banded fibrils. $\times 16,000$ approx. Scale marker 1 micron. 
that described as "fibrinoid" by Cochrane, Davies, Dowling, and Bywaters (1964) in the rheumatoid nodule. The material has many similarities in fine structure to the fibrin bodies which can be washed from the synovial cavity in rheumatoid patients and prepared in the routine way for electron microscopy.

The synovial membrane was infiltrated with many neutrophils (Fig. 2), plasma cells (Fig. 3), lympho-

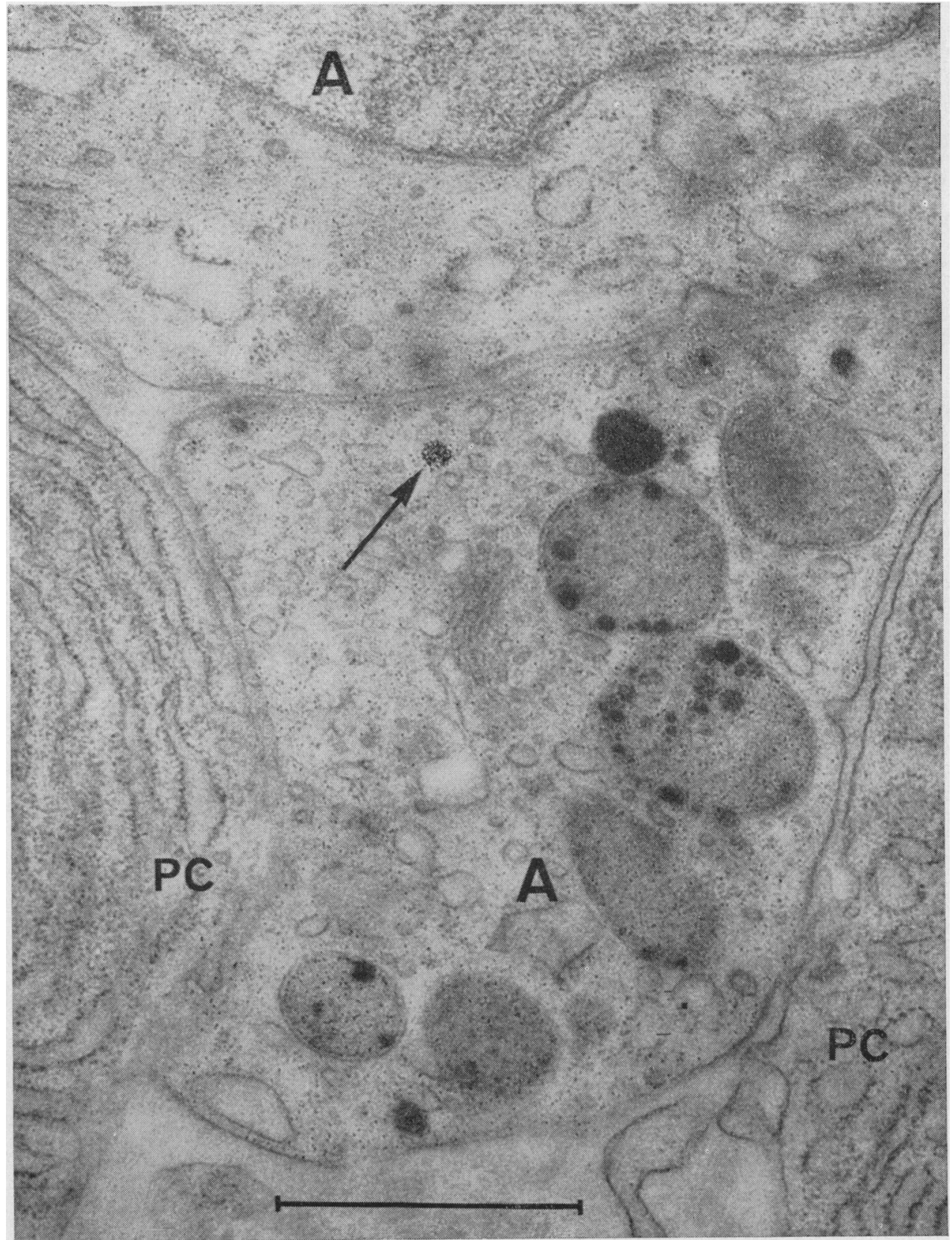

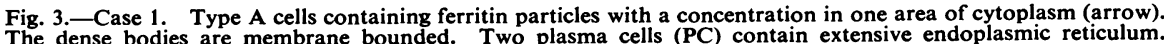

$$
\times \mathbf{4 0 , 0 0 0} \text {. Scale marker } 1 \text { micron. }
$$


cytes, and less frequently eosinophils and mast cells. Numerous small blood vessels were visible and the endothelial and perivascular cells appeared to be essentially normal.

Our chief interest has, however, been with the synovial lining cells themselves. The cell most commonly seen usually had a regular surface containing occasional pinocytotic vesicles and surface "pits" (Fig. 4). The cytoplasm contained many mitochondria which in most cells appeared quite normal. A few cells did have swollen mitochondria with a shortened cristae but the infrequency of this finding makes it of doubtful significance. A Golgi complex was a prominent feature and the cytoplasm contained many small rounded or oblong vesicles 0.08 to 0.2 microns in diameter. A small amount of rough-surfaced endoplasmic retuculum appeared in these cells usually in the peri-nuclear position and the cytoplasm may contain fine filaments. Large vacuoles were rarely seen.

The two most striking features were first, the presence of complex dense bodies frequently occupying large areas of the cell, and secondly, tiny granules scattered throughout the cytoplasm which had the characteristic appearance of ferritin. Both these features are further described below. The nucleus contained granular nucleoplasm and one or two nucleoli were usually present. The nuclear membrane had no unusual features.

This cell, apart from the rarity of large vacuoles, the presence of ferritin and the enlargement and appearance of the dense bodies, corresponds with the type $A$ or $M$ cell. It may be distinguished from typical examples of the type B or F cell (Fig. 5, opposite), whose cytoplasm contains abundant endoplasmic reticulum.



Fig. 4.-Case 2. Dense bodies in a type A synovial cell; vacuoles (V) and a mitochondrion (M) are visible. The cell surface shows both "pits" (arrows) and also pinocytotic vesicles. $\times 38,500$. Scale marker 1 micron. 


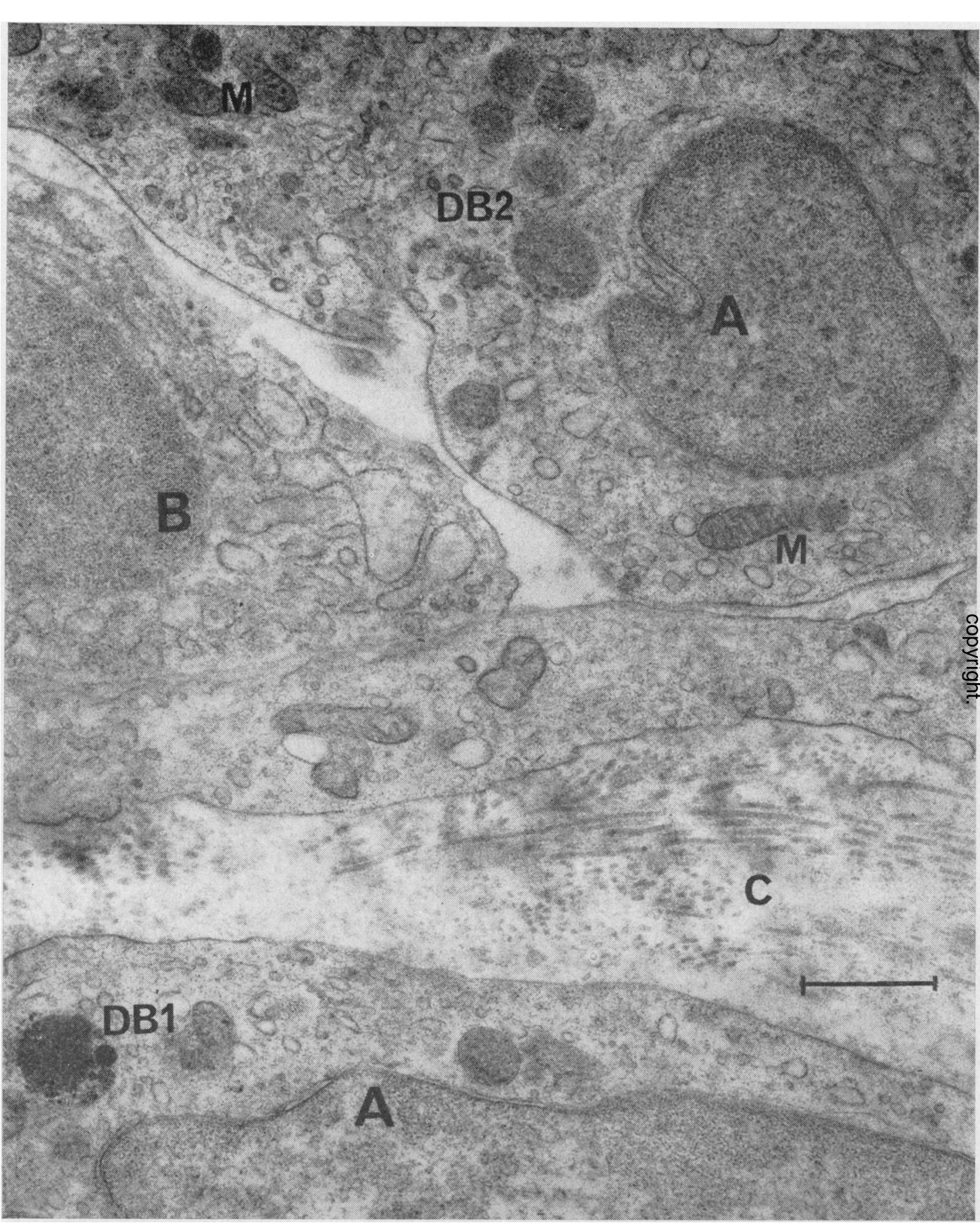

Fig. 5.-Case 1. Areas of three type Assynovial cells.(A) with one type B endoplasmic reticulum rich cell (B). The type A cells contain many mitochondria (M) and also dense bodies' (DB 1 and 2). The inter-cellular spaces contain banded collagen fibres (C). $\times 18,600$ approx. Scale marker 1 micron. 
Apart from the occasional presence of ferritin granules, the type B cell had the same structure as in the normal synovial membrane. It appeared to be much less frequent than the type A cell in the areas examined.

It has been mentioned that one striking feature of the type A cell in these three biopsies was the presence of large cytoplasmic dense bodies which range in size from 0.3 to 3.0 microns in diameter. It was usually possible to distinguish a membrane around these bodies which occasionally was doubled. The larger bodies ( 1.0 microns and more in diameter) had a complex structure consisting of very dense inclusions of approximately $\mathbf{0 . 3}$ microns diameter. High resolution micrographs (Fig. 6) demonstrated that these inclusions contained innumerable ferritin granules lying on a background of even density.

Other dense bodies (Fig. 7, opposite) also contained ferritin but the background was uniform and less dense. Gradations between both types of cytoplasmic body were seen (Fig. 3). Less commonly ferritin was concentrated into a vacuolated area with a clear background (Fig. 8, overleaf).

The cytoplasm itself may also contain large numbers of ferritin molecules scattered freely (Fig. 7, and Fig. 9, overleaf) but they were usually not seen in the small vesicles, in mitochondria or in the few large clear vacuoles. The typical structure of the ferritin molecule can be seen in Fig. 10 (overleaf).

The dense bodies were not commonly seen in the type B cell. When present ferritin was in much lower concentrations than in the type A cell. This pattern of distribution of ferritin is identical with that found in experiments in which a solution of ferritin was injected into the joint cavity in rabbits. Ferritin particles appeared concentrated in the type A cell whilst the type $B$ cell generally remained free of ferritin (Muirden, 1963).

It is not possible to say with any certainty what proportion of the type A cells contained ferritin. In Case 1 almost all the cells of this type examined from at least five different areas of synovium con-

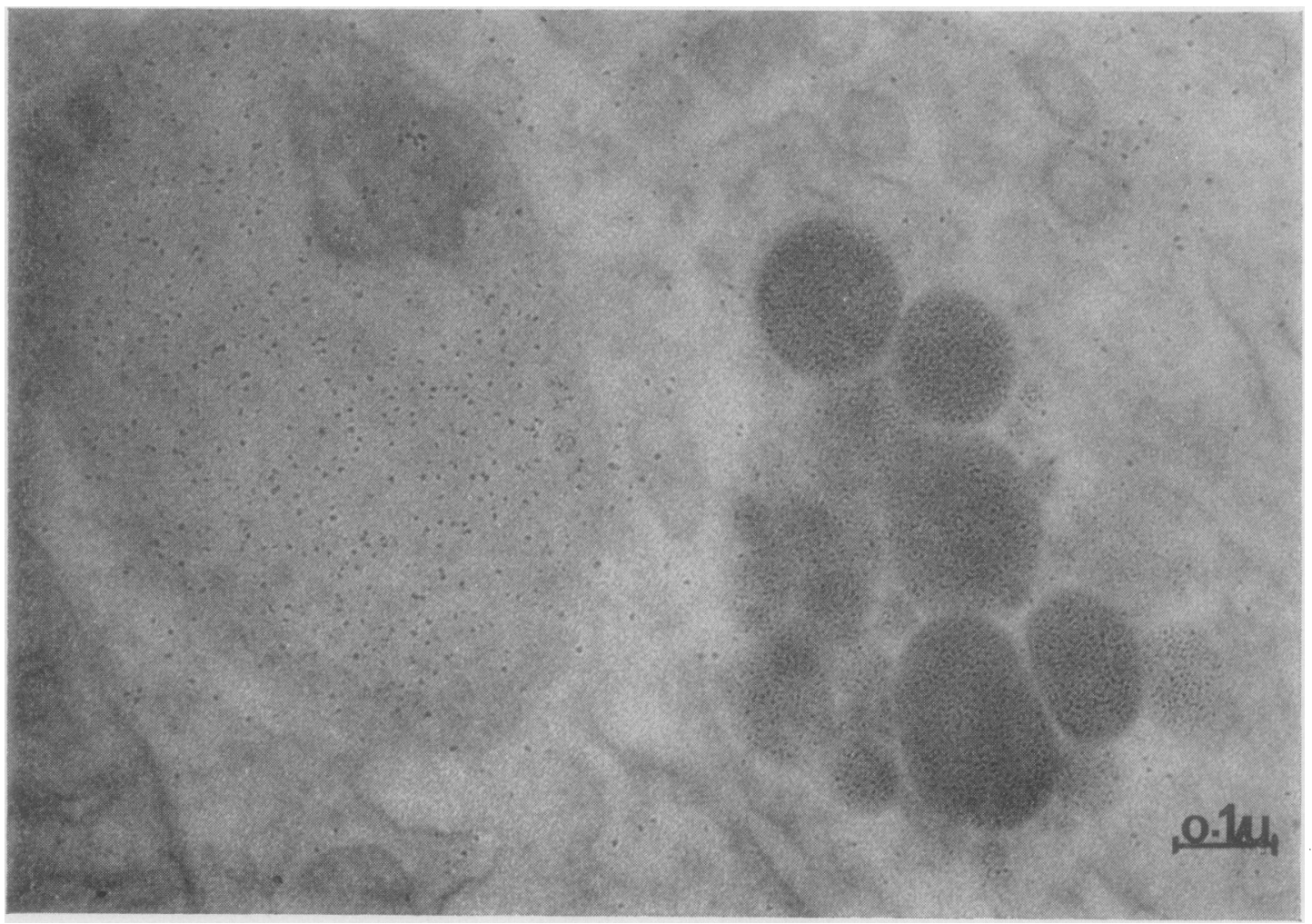

Fig. 6. - Case 1. High magnification of part of the cytoplasm of a type A cell. Ferritin molecules are concentrated into both types of dense body but particularly into the very dense inclusions on the right. $\times 106,000$. Scale marker $0 \cdot 1$ micron. 


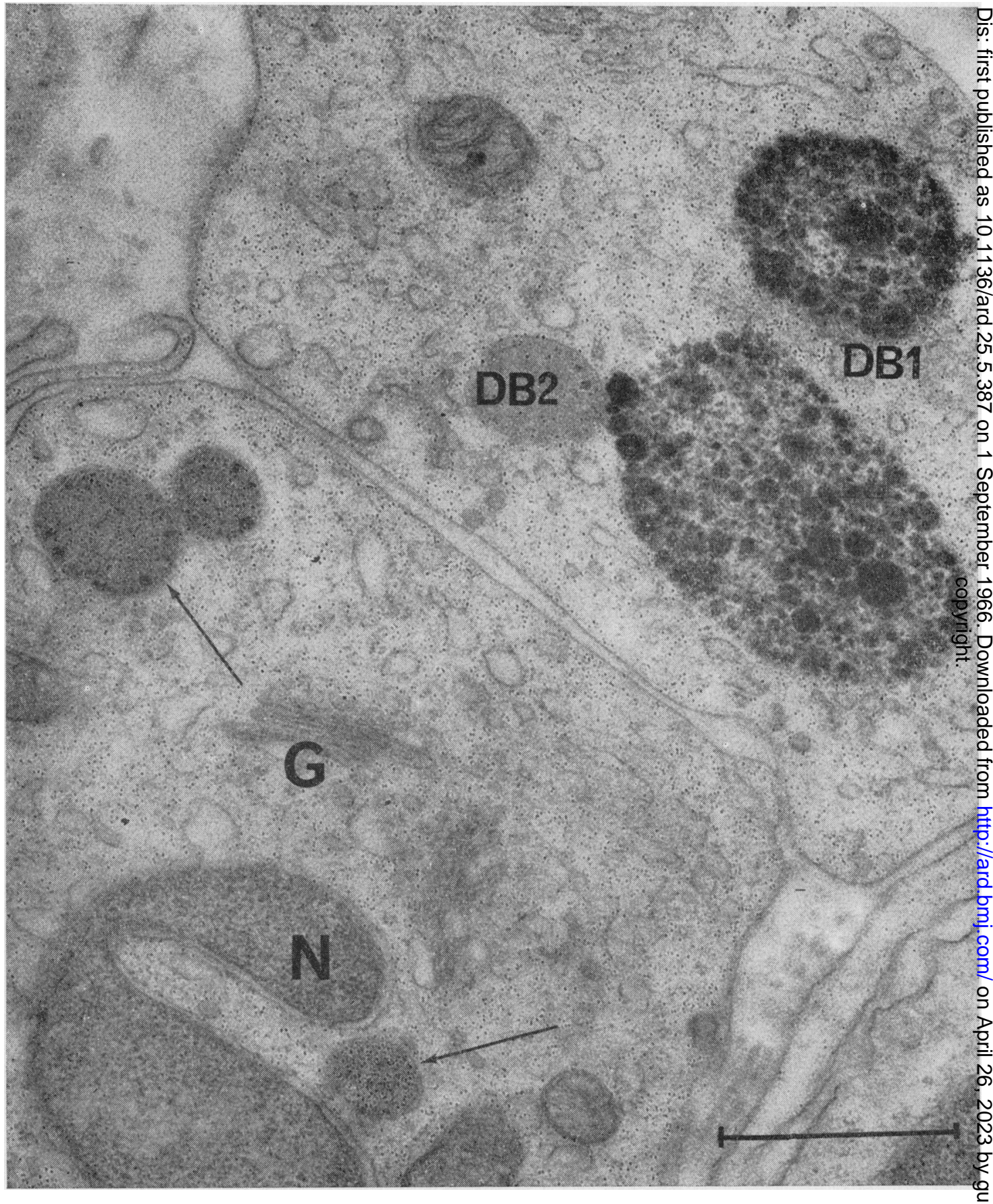

Fig. 7.-Case 1. Type A synovial cells; the lower cell nucleus $(N)$, contains a prominent Golgi zone (G) Ferritin granules are scattered throughout the cytoplasm and even extend into the filipodia. The upper cell contains two types of dense body (DB 1 and 2), and it can be seen that ferritin is concentrated into the dense bodies in the lower cell (arrows). $\times 35,000$. Scale marker 1 micron. 


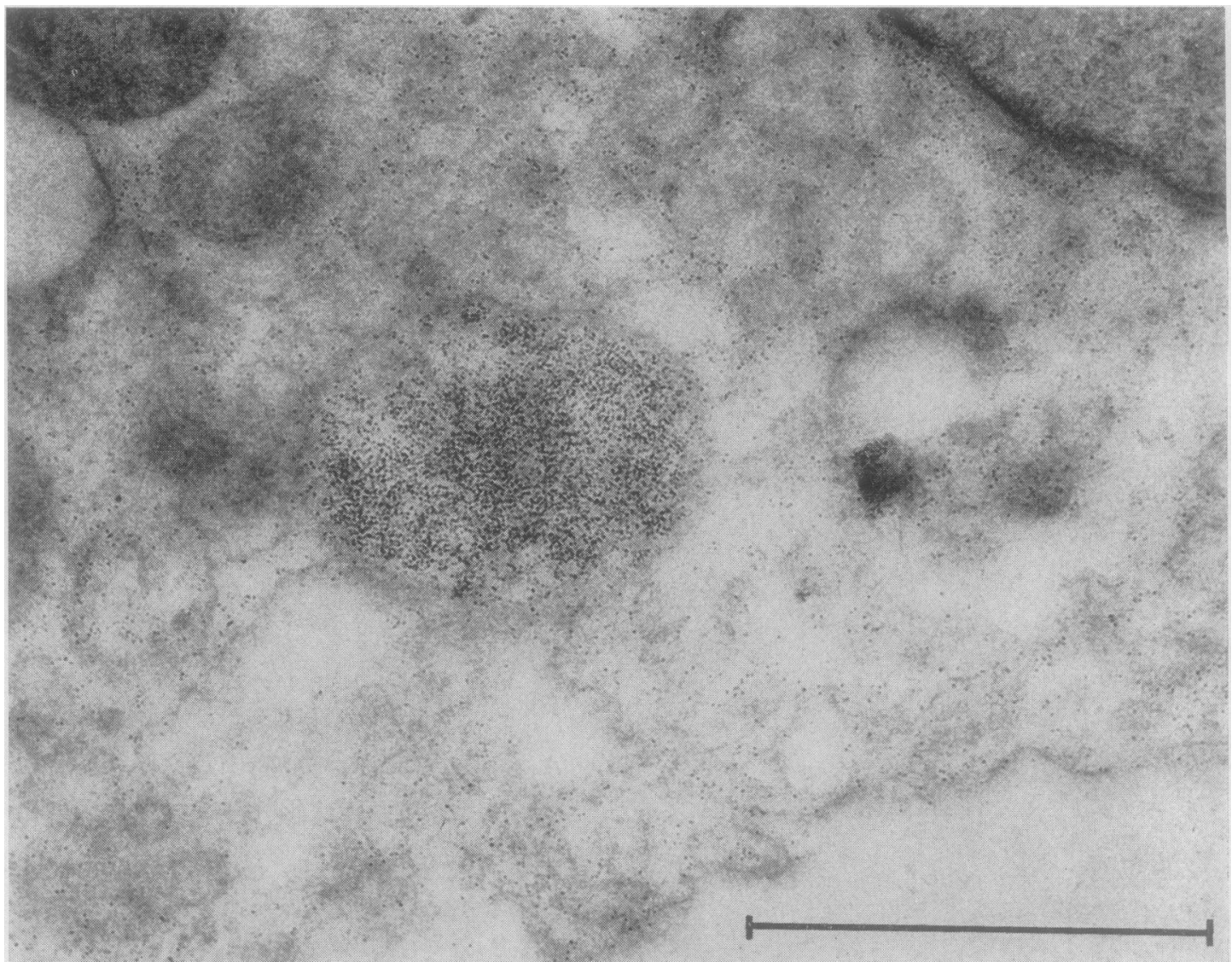

Fig. 8.-Case 3. Ferritin particles are concentrated into a vacuole in a type A cell. Particles are also scattered in the cytoplasm. $\times 55,000$. Scale marker 1 micron.

tained ferritin. In Cases 2 and 3 many type $A$ cells did not. Neutrophils, plasma cells and lymphocytes together with the extra cellular spaces were found to be free of ferritin.

When the original paraffin embedded tissue was reexamined following preparation with a Prussian blue stain for iron it was found that scattered deposits of iron were visible in both the superficial synovial cells and the deeper tissue. The staining was patchy but quite definite in Cases 1 and 2 where material was available for examination.

In Fig. 11 (opposite), iron staining is marked in the surface area of a synovial villous.

\section{Discussion}

Cytochemical studies have demonstrated the presence of lysosomal enzymes, in particular acid phosphatase activity, in both normal and arthritic synovial tissue (Hamerman, Stephens, and Barland,
1961). In rheumatoid arthritis the acid phosphatase staining granules appeared more numerous and larger than in the normal synovial membrane under light microscopy. Luscombe (1963) has found increases of several lysosomal enzymes in rheumatoid synovium when compared with controls, and elevated levels of acid phosphatase have been reported in synovial fluid (Smith and Hamerman, 1962). The

Fig. 9.-Case 2. A unit membrane surrounds collections of ferritin in a synovial cell, nucleus $(N)$. Some particles also appear free in the cytoplasm. $\times 32,000$. Scale marker 1 micron.

Fig. 10 (inset).-Case 1. The typical structure of ferritin is resolved (arrow). $\times 230,000$. Scale marker 0.1 micron.

Fig. 11.-Case 2. Light microscope picture of synovial surface area the lumen is indicated (L). This was taken with an orange filter so that the Prussian blue stained areas of iron stand out a dense black against the grey cellular background. $\times 150$ 

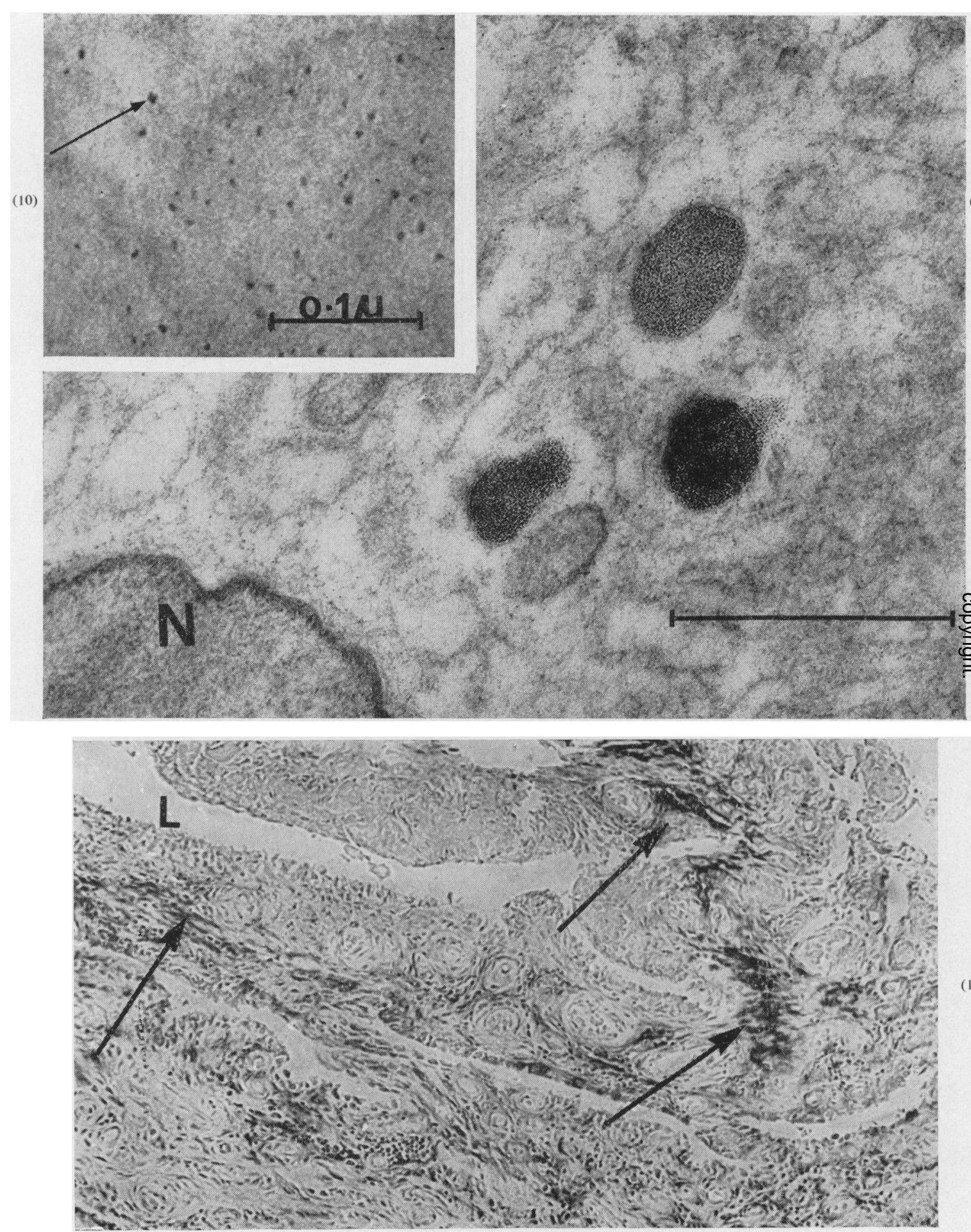
electron microscope studies of Barland and others (1964) have shown the presence of large complex cytoplasmic granules with acid phosphatase staining indicating that they are lysosomes. The cytoplasmic dense bodies described in these three patients are similar in appearance and although acid phosphatase localisation has not been attempted it is appropriate to consider these as lysosomes. Their size, number and bizarre appearance contrast with the smaller dense bodies of the normal synovium.

The appearance of ferritin in these dense bodies, previously unreported, does not contradict the view that they are lysosomes. Biochemical and morphological studies have indicated the association of ferritin particles with organelles containing acid phosphatase in hepatic parenchymal cells, Kupffer cells, and splenic macrophages (Novikoff, 1961), and in renal tubule cells (Ericsson, Trump, and Weibel,
1965). In fact the cytoplasmic bodies here shown in Figs 7 and 12 appear identical with the lysosome 3 shown in the paper by Essner and Novikoff (1961, 응 Fig. 3), which illustrates a Kupffer cell from the liver of a normal mouse.

The presence of ferritin within lysosomes and vacuoles and also scattered free in the cytoplasm of rheumatoid synovial cells invites speculation as to the $\overline{\bar{n}}$ immediate origin of the iron.

Ferritin is the chief storage form of iron in the body. The molecule contains 23 per cent. iron or ${ }^{\text {s }}$ 2,000 iron atoms and its molecular weight is 560,000 . $\vec{\circ}$ Its unique appearance in the electron microscope has made it invaluable in tracer studies. It may normally be found in the reticular cells of the bone marrow oro spleen, in hepatic cells, and in the intestinal epithelium, and occasionally it is seen in kidney tubulecr cells. The iron storage granule haemosiderin,

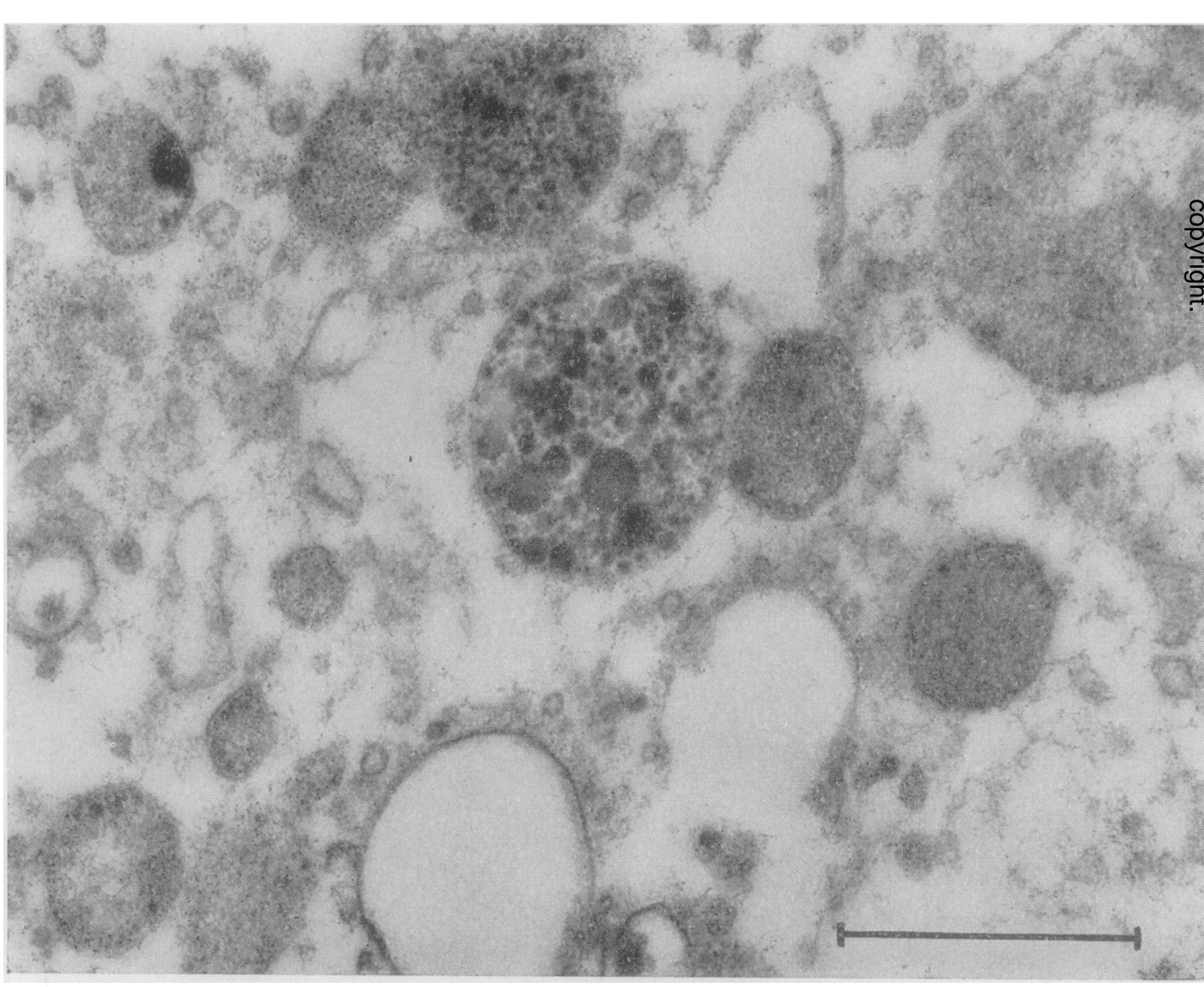

Fig. 12.-Case 3. Both types of dense body occur in this type A cell. Scattered ferritin particles are visible. $\times 35,000$. Scale marker 1 micron. 
although inconstant in composition, rarely fails to contain ferritin (Bessis and Breton-Gorius, 1962). In reticular cells ferritin may be scattered in the cytoplasm or found in large or small aggregates which may or may not be surrounded by a double membrane.

In considering ferritin in liver lysosomes, Novikoff, Essner, and Quintance (1964) speculated that the molecules originate from degenerating mitochondria within the cell itself, perhaps from the iron-containing cytochromes in the microchondria. But the amount and distribution of ferritin seen in synovial cells in this study make it much more likely that the iron necessary for its formation arises outside the cell, either directly from the circulation where iron is carried as siderophilin, or from red blood cells in the synovial fluid.

One function of lysosomes is the intra-cellular digestion of phagocytosed protein, carbohydrate, and other material. After injection of certain macromolecules, such as thorium dioxide, colloidal gold, carbon suspensions, etc., it is possible to demonstrate these particles within lysosome-like structures in the liver (Weissman, 1965). It has long been recognized that particles introduced into the blood are also deposited in cells of the synovial membrane and that the amount deposited is increased in the presence of local inflammation (Kuhns and Weatherford, 1936). Another possibly pertinent observation is that of McCarthy, Reid, and Gibbons (1964) relating to macrophages in the lung. In these experiments various types of mucin injected into the alveoli of rats via the bronchi were incorporated into macrophages. Subsequently the macrophages showed staining reactions for iron. It was suggested that the affinity of mucopolysaccharides for iron was sufficient to cause it to accumulate in macrophages. It must be added that these authors did not claim to demonstrate ferritin by their histochemical techniques, but the haemosiderin which they did demonstrate is usually associated with an increase in ferritin (Richter, 1957; Bessis and Breton-Gorius, 1962). The situation of synovial cells producing and possibly absorbing the mucopolysaccharide hyaluronic acid invites comparison.

The alternative suggestion that the ferritin in synovial cells originates from the synovial fluid, in fact after haemorrhage into the synovial cavity, is also worth considering. Experiments in which irondextran or ferritin itself was injected into the synovial cavity of rabbits did produce a distribution of cellular ferritin which was identical with that seen in these three biopsies. Not only was the different absorption capacities of the two types of lining cell maintained, but the distribution of ferritin scattered in the cell cytoplasm or concentrated into dense bodies or vacuoles was similar in experimental animals and in rheumatoid tissue (Muirden, 1963; Ball, Chapman, and Muirden, 1964). The injected iron dextran was converted to ferritin after absorption into synovial cells and we have recently shown that synovial cells in culture will form ferritin from very low concentrations of haemoglobin introduced into the culture medium (Muirden and Fraser, 1966).

There was no history of trauma to explain joint haemorrhage in the three cases reported here. However, red blood cells may be seen in rheumatoid synovial fluids in the absence or recent trauma, and in Case 1 the synovial fluid aspirated from the knee was visibly blood stained 9 days before surgery. It is possible that, in advanced rheumatoid disease with irregular joint surfaces, deformity, and instability, simple weight-bearing may add a "traumatic" element which is not recognizable as an obvious injury.

Although it is possible only to speculate on whether the bulk of the ferritin in synovial cells arises directly from the plasma or from the synovial fluid, there are two points of possible significance. Attempts have been made to implicate abnormal lysosomal fragility in synovial membrane cells and in cells of the synovialo fluid in the pathogenesis of rheumatoid disease Most of the evidence is as yet circumstantial but it is likely that the erosion of cartilage is due to the release? of lysosomal enzymes from cells of the invading pannus (Dingle, 1962). Further experimental support for this theory is provided by Weissman, Becher, Wiederman, and Bernheimer (1965). It has been suggested by de Duve (1963) that lysosomes containing phagocytosed material discharge their contained hydrolytic enzymes more readily than do normal or unaltered lysosomes. Evidence to support this concept is discussed by Weissman (1965). Thus Astorga and Bollet (1965) have shown that phagocytosis of rheumatoid factor-gamma globulin precipitates by leucocytes in vitro caused activation of lysosomal enzymes. With this information Zvaifler (1965) has postulated that the joint inflammation in rheumatoid arthritis is a consequence of the interaction of an altered gamma globulin molecule with rheumatoid factor in the synovial fluid. The product of this interaction, the inclusion body, is phagocytosed by leucocytes with consequent release of hydrolytic enzymes from the lysosomes. These enzymes then produce joint tissue damage directly or by the release of a number of pharmacologically active substances such as kinins. Zvaifler further argued that such a specific initiating event is unnecessary but that the rheumatoid patient provides a unique milieu in 
which any insult capable of producing joint inflammation could set in motion such a self-perpetuating series of events. One such stimulus could be trauma and joint haemorrhage, which does produce synovial inflammation in man and experimental animals (Key, 1929; Wolf and Mankin, 1965). The incorporation of iron as ferritin in the synovial cell lysosomes is then a step in a vicious circle initiated in a susceptible person by trauma and perpetuated by the release of lysosomal enzymes producing further tissue damage and haemorrhage.

It is worth adding that synovial deposition of iron may be responsible occasionally for symptomatic arthritis in haemochromatosis (Kra, Hollingsworth, and Finch, 1965). The chronic arthritis following repeated haemarthrosis in haemophilia is well documented and invasion of cartilage by vascular connective tissue or pannus may occur (Key, 1932).

The other possible significance of finding extensive ferritin deposits in rheumatoid synovial cells concerns the anaemia of rheumatoid arthritis. Although a considerable amount of work has been done on this subject, the exact cause of the anaemia remains uncertain. However, the low serum iron, the hypochromic blood picture, and the reduced iron stores in the marrow which are often seen does suggest an abnormality in iron metabolism (Jeffrey, 1965). Apparently there is no abnormality of iron transport in plasma as the iron-binding capacity is normal or increased and there is no evidence of a qualitative alteration. Iron is normally absorbed from the gut (Roy, Alexander, and Duthie, 1955), and chronic blood loss from the gastrointestinal tract cannot explain the majority of cases of anaemia. The recent studies of Raymond, Bowie, and Dugan (1965) have emphasized that there is an increased plasma clearance of iron and it has been suggested that the reticulo-endothelial cells and perhaps hepatic parenchymal cells may be unusually avid for iron. A parallel could exist here with the anaemia of infection and inflammation, where it has been reported that there is defective re-utilization of iron probably related to a defect in release of iron from storage sites, principally the liver and spleen (Haurani, Burke, and Martinez, 1965). One attempt to demonstrate the concentration of iron in the visceral organs in rheumatoid arthritis showed there was no significant increase compared with control cases in patients who had not received iron therapeutically with the possible exception of the spleen (Gardner and Roy, 1961).

Could it be that the synovial deposits of ferritin in rheumatoid arthritis represent iron which is sequestrated in this situation? The innumerable ferritin particles shown in such a small area of tissue relative

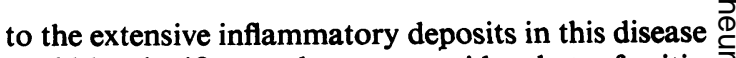
could be significant when we consider that a ferritin 3 molecule contains 2,000 iron atoms. If the release $\frac{}{6}$ of iron from this sizeable store is impeded, anaemia could well be the result. It is to be noted that anaemia was present in all three cases and was severe in two.

\section{Summary}

Synovial tissue removed at open operation in कs cases of rheumatoid arthritis was examined with the $\vec{\circ}$ electron microscope. In three consecutive cases the most striking feature was the presence of large num- $\vec{\omega}$ bers of ferritin molecules particularly in type $A$ synovial lining cells. The ferritin was scattered throughout the cell cytoplasm but was frequently जั concentrated into complex cytoplasmic granules or $i$ lysosomes.

The possible significance of this finding in relation to the anaemia and pathogenesis of rheumatoid $\frac{}{2}$ arthritis is discussed.

I am grateful to Drs. J. L. Frew and R. F. A. Strang for $\frac{\mathbb{Q}}{\mathbb{0}}$ permission to report clinical details of Case 2, to Mr.W.E. Swaney and Mr. K. W. Mills for providing the biopsy material, to Mr. Keith Rogers for technical assistance and to Professor R. R. H. Lovell and Dr. J. R. E. Fraser for $\vec{\bullet}$ advice and encouragement. I am indebted to Mr. Gorden Senator for taking the light microscope picture, Fig.

\section{REFERENCES}

Astorga, G., and Bollet, A. J. (1965). Arthr. and Rheum., 8, 511.

Ball, J., Chapman, J. A., and Muirden, K. D. (1964). J. Cell Biol., $22,351$.

Barland, P., Novikoff, A. B., and Hamerman, D. (1962). Ibid., 14, 207.

-,-- (1964). Amer.J. Path., 44, 853.

Bessis, M. C., and Breton-Gorius, J. (1962). Blood, 19, 635.

Chapman, J. A., Muirden, K. D., Ball, J., and Hyde, P. A. (1962). In "Electron Microscopy. Proceed-i ings of the Fifth International Congress", ed. $\frac{\mathrm{O}}{3}$ S. S. Breeze, Jr., vol. 2, p. SS-12. Academic Press Inc., New York.

Cochrane, W., Davies, D. W., Dowling J., and Bywaters, E. G. L. (1964). Ann. rheum. Dis., 23, 345.

$\longrightarrow,-$, and Palfrey, A. J. (1965). Ibid., 24, 2.

de Duve, C. (1963). In "Ciba Foundation Symposium: Lysosomes", ed. A. V. S. de Reuck, and M. P.N Cameron, p. 1. Churchill, London.

Dingle, J. T. (1962). Proc. roy. Soc. Med., 55, $109 . \quad \omega$ Essner, E., and Novikoff, A. B. (1961). J. biophys:? biochem. Cytol., 9, 773.

Ericsson, J. L. E., Trump, B. F., and Weibel, J. (1965). Lab. Invest., 14, 1341. 
Gardner, D. L., and Roy, L. M. H. (1961). Ann. rheum. Dis., 20, 258.

Glauert, A. M., and Glauert, R. H. (1958). J. biophys. biochem. Cytol., 4, 191.

Hamerman, D., Stephens, M., and Barland, P. (1961). In "Inflammation and Diseases of Connective Tissue: A Hahnemann Symposium", ed. L. C. Mills and J. H. Moyer, pp. 158-168. Saunders, Philadelphia.

Haurani, F. I., Burke, W., and Martinez, E. J. (1965). J. Lab. clin. Med., 65, 560.

Hirohata, K., and Kobayashi, I. (1964). Kobe J. med. Sci., 10, 195.

—, Mizuhara, K., Fujiwara, A., Sato, T., Imura, S., and Kobayashi, I. (1963). J. Jap. orthop. Ass., $36,10$.

Jeffrey, M. (1965). In "Progress in Clinical Rheumatology", ed. A. St. J. Dixon, pp. 27-41. Churchill, London.

Key, J. A. (1929). J. Bone Jt Surg., 11, 705.

(1932). Ann. Surg., 95, 198.

Kra, S. J., Hollingsworth, J. W., and Finch, S. C. (1965). New Engl. J. Med., 272, 1268.

Kuhns, J. G., and Weatherford, H. L. (1936). Arch. Surg., 33, 68.

Luscombe, M. (1963). Nature (Lond.), 197, 1010.

McCarthy, C., Reid, L., and Gibbons, R. A. (1964). J. Path. Bact., 87, 39.

Muirden, K. D. (1963). Arthr. and Rheum., 6, 289.

- and Fraser, J. R. E. (1966). Unpublished observations.

Norton, W. L., and Ziff, M. (1964). Arthr. and Rheum., $7,335$.

Novikoff, A. B. (1961). In "The Cell", ed. J. Brachet, and A. E. Mirsky, vol. 2, p. 423. Academic Press, New York.

_- Essner, E., and Quintana, N. (1964). Fed. Proc., 23, 1010.

Raymond, F. D., Bowie, M. A., and Dugan, A. (1965). Arthr. and Rheum., 8, 233.

Richter, G. W. (1957). J. exp. Med., 106, 203.

Roy, L. M. H., Alexander, W. R. M., and Duthie, J. J. R. (1955). Ann. rheum. Dis., 14, 63,

Smith, C., and Hamerman, D. (1963). Arthr. and Rheum., 5, 411.

Weissmann, G. (1965). New Engl. J. Med., 273, 1084, 1143.

Becher, B., Widermann, G., and Bernheimer, A. W. (1965). Amer. J. Path., 46, 129.

Wolf, C. R., and Mankin, H. J. (1965). J. Bone Jt Surg., 47A, 1203.

Wyllie, J. C., More, R. H., an ذ Haust, M. D. (1964). Lab. Invest., 13, 1254.

Zvaifler, N. J. (1965). Arthr. ard Rheum., 8, 289.

\section{ADDENDUM}

Since this paper was submitted for publication a further four synovial biopsies have been examined with the electron microscope. Ferritin granules have been identified in synovial cells in all of these cases with the lysosomal appearance as shown in Figs 7 and 12 being prominent. Light microscopy following Prussian blue staining has revealed appreciable quantities of iron, similar in distribution to that seen in Fig. 11, in twelve rhematoid biopsies with one negative result. In five non-rheumatoid control synovial biopsies, iron has not been demonstrated by the Prussian blue technique.

La ferritine dans les cellules synoviales des malades atteints d'arthrite rhumatismale

\section{RÉSUMÉ}

On examina au microscope électronique le tissu synovial prélévé à l'opération sur des cas d'arthrite rhumatismale. La trouvaille la plus frappante dans trois cas consécutifs fut la présence d'un grand nombre de molécules de ferritine, surtout dans les cellules synoviales de revêtement du type A. La ferritine se trouvait dispersée dans le cytoplasme cellulaire, mais or la voyait souvent concentrée en granules cytoplasmique complexes ou en lysosomes.

On discute la possible importance de ces observations en ce qui concerne l'anémie et la pathogénie de l'arthrite rhumatismale.

La ferritina en las células sinoviales de enfermos con artritis reumatoide

\section{SUMARIO}

Se examinó al microscopio electrónico el tejido sinovial recogido en operación abierta en casos de artritis reumatoide. El hecho más destacado fué el hallazgo en tres casos consecutivos de un gran número de moléculas de ferritina, particularmente en células sinoviales de revestimiento de tipo A. La ferritina se vió dispersada en el citoplasma celular, pero a menudo se pudo observar concentrada en gránulos citoplásmicos complejos o en lisosimos.

Se discute la importancia posible de estas observaciones respecto a la anemia y a la patogénesis de la artritis reumatoide. 